\title{
INDICATIVE APPROACH IN THE EVALUATION OF THE IMPLEMENTATION OF THE CONSTITUTIONAL RIGHT TO JUDICIAL PROTECTION IN THE STATE LANGUAGES OF THE RF SUBJECTS
}

\author{
Damir Kh. Valeev ${ }^{1}$ \\ Anas G. Nuriev ${ }^{2}$ \\ Rafael V. Shakirjanov ${ }^{3}$
}

\begin{abstract}
The implementation of the constitutional right to judicial protection is an important guarantee for participants in legal relations in case of violation of the rights of one of the parties or a threat of violation of the rights of participants in legal relations. Judicial protection is of particular relevance for the participants in legal relations, who do not speak the languages in which the administration of justice is carried out. Within the framework of this article, the authors analyze indicators that are designed to, on the one hand, signal on the current state and existing possibilities of implementing the constitutional right to judicial protection in the state languages of the subject of the Russian Federation (statistical function), and, on the other hand, determine growth drivers that can
\end{abstract}

provide language guarantees for the territory of our state, which is defined as a democratic federal legal state according to Art. 1 of the Constitution of the Russian Federation. Within the framework of this article, three indicators are highlighted and analyzed: 1) existing legal potential for the implementation of the constitutional right to judicial protection in civil cases in the state languages of the republics within the Russian Federation; 2) analysis of the practical implementation of the opportunities currently available for the implementation of the constitutional right to judicial protection in civil cases in the state languages of the republics within the Russian Federation; 3) determination of growth points in the implementation of the constitutional

\footnotetext{
${ }^{1}$ Kazan Federal University. e-mail: valeev55@gmail.com. Tel. 8432337213

${ }^{2}$ Kazan Federal University. e-mail: anasnuriev@ yandex.ru. Tel. 89872250255

${ }^{3}$ Kazan Federal University. e-mail: rakat51@mail.ru.
} 
right to judicial protection in civil cases in the state languages of the republics within the Russian Federation.

Key words: federal legal state; official language; state language of the subject of the Russian Federation; judicial defense; administration of justice in the state language of the subject of the Russian Federation.

\section{Introduction}

Functioning of the language expressed in the possibilities that the language gives its carrier determine the place of language as a means of achieving the desired result. A language deprived of its law enforcement potential obviously gives way to the main communication channel for the language represented at all transformation stages of public relations.

Language, being the main communication means, provides its native speaker with a wide range of possibilities for the implementation of his subjective rights and the performance of duties. In particular, the emergence, change, termination of existing legal relations is carried out through the appropriate actions of a person concerned or the actions of a person mediated by communication means, in particular, oral or written form of the transaction.

Language may function in two development stages of social relations: (1) material and regulatory; and (2) controversial and procedural. The stage of occurrence, change, termination of regulatory material relations is characterized by the absence of a dispute about law. Within the framework of this stage, the parties shall implement the rights and obligations stipulated by the agreement. However, if a dispute arises about the law, it becomes necessary to protect the subjective law of one of the parties, as part of the controversial procedural stage $[1,2,3,4,5]$.

\section{Methods}

The methodological basis of the study was the general provisions of the science of civil procedural law. In the study, the following methods of scientific knowledge were used: interdisciplinary, dialectical, sociological method. 


\section{Results}

As a result of the study, we determined the indicators, whose analysis allows establishing the current state and prospects for the development of the implementation of the constitutional right to judicial protection in civil cases in the state languages of the subjects of the Russian Federation with an aim of identifying the potential of the state language of the subject of the Russian Federation in law enforcement using the example of civil proceedings.

\section{Discussion}

The implementation of the constitutional right to judicial protection in civil cases in the state languages of the subjects of the Russian Federation is a manifestation of "language guarantees" established by the current legislation, provides for a set of measures aimed at developing the languages of the subjects of the Russian Federation. In particular, Part 2 of Article 26 of the Constitution of the Russian Federation [6] determines that everyone has the right to use their native language, to freely choose the language of communication, education, training and creativity.
However, the actual implementation of "language guarantees" and the availability of development prospects can be established on the basis of a set of assessment activities, which we will designate as "indicators". An assessment of the possibilities of the state language of the subject of the Russian Federation not only as communication means in regulatory material relations, but also as protection means in controversial procedural relations, allowed distinguishing three blocks of indicators. The first indicator of the assessment of the implementation of the constitutional right to judicial protection in the state language of the subject of the Russian Federation in civil matters is the analysis of the existing legal potential for the implementation of the constitutional right to judicial protection in civil cases in the state languages of the republics of the Russian Federation. The current federal legislation provides for a set of measures aimed at developing the languages of the subjects of the Russian Federation: administration of justice in the state language of the subject of the Russian Federation (Article 9 of the Civil Procedure Code of the Russian 
Federation [7], Article 12 of the Administrative Procedure Code of the Russian Federation [8], Article 18 of the Criminal Procedure Code of the Russian Federation [9]) ; using the services of a translator (Article 33 of the Federal Law on the Constitutional Court of the Russian Federation [10], Article 9 of the Civil Procedure Code of the Russian Federation, Article 12 of the Arbitration Procedure Code of the Russian Federation [11], Article 12 of the Administrative Procedure Code of the Russian Federation, Article 18 of the Criminal Procedure Code of the Russian Federation).

At the same time, the fixed "language guarantees" in the field of civil proceedings can be designated as guarantees of "general orientation", since there are questions regarding the regulaotry certainty of particular procedural actions, the author's conclusions on which are contained in the third block "determining growth points in the issue under consideration": - possibility of making the decision text in the state language of the subject of the Russian Federation in civil proceedings. In our opinion, the preparation of judicial acts in civil cases in the case of proceedings in the state language of the subject of the Russian Federation shall be carried out by analogy with Article 12 of the Administrative Procedure Code of the Russian Federation. That is, the decision text in a civil case shall be set forth in Russian, and it is translated into the language used during the trial at the request of the parties. At the same time, in our opinion, this rule shall also be interpreted broadly, that is, the very fact of expressing a desire to consider a civil case in the state language of the subject of the Russian Federation shall be regarded as a request of the party to translate the text of the court decision into the state language of the subject of the Russian Federation.

-possibility to compile and use procedural documents in the state language of the subject of the Russian Federation. Analysis of the relevant norms of the Civil Procedure Code (Articles 3, 13, 35, 48, 53, 67, 71, etc.) shows the absence of special normative regulation regarding compilation and use of procedural documents in the state language of the subject of the Russian Federation. Thus, for example, Part 2 of Article 71 of the Civil Procedure Code of 
the Russian Federation establishes that written evidence is presented in the original form or in the form of a duly certified copy.

At the same time, special regulation with regard to "language" guarantees is available only for documents produced in a foreign language. In particular, according to Part 2 of Article 408 of the Civil Procedure Code of the Russian Federation, documents drawn up in a foreign language shall be submitted to the courts in the Russian Federation with a duly certified translation into Russian. In accordance with Article 417.4 of the Civil Procedure Code of the Russian Federation, the statement of claim in a dispute with a foreign state shall be supplemented with a duly certified translation of the statement of claim and the documents attached to it into the official language or one of the official languages of the foreign state involved in the case. A similar procedure is established in the Administrative Procedure Code of the Russian Federation (Article 70) and the Criminal Procedure Code of the Russian Federation (Article 453).
Thus, special normative regulation has not been established in the Civil Procedure Code of the Russian Federation in relation to the procedural documents made in the state language of the subject of the Russian Federation and used at various stages of civil proceedings. A systematic analysis of the Civil Procedure Code of the Russian Federation, the Criminal Procedure Code of the Russian Federation, Administrative Procedure Code of the Russian Federation allows making a conclusion that there is only one legislative restriction regarding the use of the state language of the subject of the Russian Federation in the preparation of procedural documents. It relates to a court decision in administrative proceedings, and for the rest it is possible to draw up procedural documents both by the participants in the process and by the judicial authority in the state language of the subject of the Russian Federation when administering justice in the court of first instance and appeal court, if it is located on the territory of the republic.

It seems that the fact of applying to court in the state language of the subject of the Russian Federation, 
guaranteed by the Constitution of the

Russian Federation, does not mean the will to send civil proceedings in the state language of the subject of the Russian Federation, since it is necessary to establish the possibility of a judicial authority to exercise the right to judicial protection in the state language of the subject of the Russian Federation. As a rule, this circumstance can only be established at a preliminary hearing. In addition, it is required to establish the position of the other side in this case; however, it should be noted that the position of the other side cannot impede the consideration of the case in the state language of the subject of the Russian Federation, since the constitutional guarantees determine that everyone has the right to use their own language, to freely choose a language of communication, education, training and creativity. In this case, the court, having the opportunity to consider the case in the state language of the subject of the Russian Federation, shall provide the defendant with a translation of the procedural documents.

Practice shows that often the courts refuse to consider civil cases in the state language of the subject of the
Russian Federation for no apparent reason. It seems that the possibility of appealing against a court ruling on refusal to consider a case in the state language of the subject of the Russian Federation shall find its regulatory fixation. This norm, being universal, would make it possible for people, applying to the court, to appeal other decisions of the court of first instance that impede the implementation of the fundamental rights and freedoms of a citizen established by the Constitution of the Russian Federation.

- determination of the legal status of an interpreter in civil proceedings. Despite the importance of the procedural function implemented by the interpreter in the Civil Procedure Code of the Russian Federation, there is no legal definition of the interpreter as a participant in procedural relations. The most complete is the definition of the interpreter given in Article 52 of the Administrative Procedure Code of the Russian Federation as a person fluent in the language in which administrative proceedings are conducted, and in another language, knowledge of which is necessary for translation from one language to another, or a person fluent in 
the communication technique with the deaf, dumb, deaf and dumb. In all procedural sources, the main criterion characterizing the interpreter is fluency in the language of the proceedings and the language, whose knowledge is necessary for the translation. At the same time, the legislation does not provide for determining the level of free language proficiency through the establishment of minimum requirements for the interpreter. Moreover, there are no additional requirements, for example, related to the presence of special education or membership in a selfregulatory organization of judicial interpreters.

The second indicator of the assessment of the implementation of the constitutional right to judicial protection in the state language of the subject of the Russian Federation in civil cases is the analysis of practical implementation of the available opportunities at present.

The third indicator for assessing the implementation of the constitutional right to judicial protection in the state language of the subject of the Russian Federation in civil matters is the determination of growth points in the matter under consideration.
Growth points are determined taking into account the conclusion about the effect of "language guarantees" in two planes: implementation of the administration of justice in the state language of the subject of the Russian Federation and the possibility of using the services of the interpreter. Regarding the implementation of the administration of justice in the state language of the subject of the Russian Federation, when setting out the text of a court decision in the state language of the subject of the Russian Federation, the norm shall be interpreted broadly, that is, the very fact of expressing a desire to consider a civil case in the state language of the subject of the Russian Federation shall be regarded as a request of the party to translate the text of the court decision into the state language of the subject of the Russian Federation.

An analysis of the legislative provisions formulated in the Civil Procedure Code of the Russian Federation, and in case of their absence, borrowed by analogy of the law (Part 4 of Article 1 of the Civil Procedure Code of the Russian Federation) in related procedural sources allows identifying the following criteria that a person acting 
in the civil process as the interpreter shall meet. As the first criterion, one can single out fluency in the language in which the proceedings are being conducted and the language, whose knowledge is necessary for translation. Due to the fact that the judge is entrusted with the obligation to resolve the issue of involving the interpreter in the process in accordance with Article 150 of the Civil Procedure Code of the Russian Federation, he/she shall establish the level of fluency in the language. At the same time, a judge who involves an interpreter in the process due to his/her lack of special knowledge cannot guarantee the level of fluency in the language, taking into account the specific nature of a particular civil case. In this case, the level of language proficiency is established during the consideration of the case, taking into account the opinions of persons participating in the case and contributing to the administration of justice. The second criterion is the mandatory procedural legitimization of a person, who is fluent in the languages necessary for the administration of justice.

Accordingly, subject to the above two criteria, a person can be involved in the case as the interpreter and the result of his/her activities will be presumed to be appropriate. This means that proof of the fact of correct and undistorted translation is not required. However, in this case we are talking about relative presumption, since the case can be reconsidered due to newly discovered circumstances, if a deliberately incorrect interpretation is established by an effective court verdict (court order). At the same time, in the absence of intent in the interpreter's actions, who, due to the specific nature of the civil case under consideration, has distorted the facts needing to be investigated, the court applies sanction provided for by Article 330 of the Civil Procedure Code of the Russian Federation - review of the case on unconditional procedural grounds in the court of appeal.

\section{Conclusions}

Based on the study, it can be concluded that the selected indicators reveal the law enforcement potential and practical implementation of the state language of the subject of the Russian Federation as a means of protecting violated substantive law. The applied 
value is expressed in the fact that it is proposed to prepare recommendations on the use of the state language of the subject of the Russian Federation in legal proceedings on the basis of the study.

\section{Acknowledgements}

The work is performed according to the Russian Government Program of Competitive Growth of Kazan Federal University.

The reported study was funded by RFBR according and the Government of the Republic of Tatarstan to the research project № 18-411-160004 r_a.

\section{Bibliography}

Damir Kh. Valeev, Anas G. Nuriev. , Rafael V. Shakirjanov Implementación del derecho constitucional a la protección judicial en los idiomas estatales del sujeto de la Federación Rusa // Revista Dilemas Contemporáneos: Educación, Política y Valores. - Año: VI. -Número: Edición Especial . - Artículo no.:24. - Período: Diciembre 2018.

Nuriev A.G., Khodzhiev A.R, Procedural guarantees of rights of citizens of the Russian federation in the foreign states//Research Journal of
Applied Sciences. - 2015. - Vol.10, Is.12. - P.832-834.

Safin Z.F. Legal Issues Supporting Production and Distribution of Biotech Products / E. V. Luneva, Z. F. Safin // International journal of Advanced biotechnology and Research. - 2016. Vol. 7. - № 4. - P. 1260-1264.

Valeev D.K., Golubtzov V.G. Modernization of the Russian law: a review of the laws on enforcement proceedings // Life Science Journal. 2014. №11(8s). P. 234-238.

Anas G. Nuriev. Características de la Responsabilidad Civil del Notario // Revista Dilemas Contemporáneos: Educación, Política y Valores. - Año: VI. -Número: Edición Especial . - Artículo no.:31. - Período: Diciembre 2018.

Constitution of the Russian Federation // Official Gazette dated December 25, 1993.

Civil Procedure Code of the Russian Federation dated November 14, 1992 // Official Gazette of the Russian 
Federation. - dated November 18, 2002.

- No. 46. - Art. 4532.

Administrative Procedure Code of the

Russian Federation dated March 8, 2015

// Official Gazette of the Russian

Federation. - dated March 09, 2015. -

No. 10. - Article - 1391.

Criminal Procedure Code of the Russian

Federation dated December 18, $2001 / /$

Official Gazette of the Russian

Federation. - dated December 24, 2001.

- No. 52 (Part One). - Art. - 4921.

Federal Constitutional Law No. 1-FKZ dated July 21, 1994 "On the Constitutional Court of the Russian Federation" // Official Gazette of the Russian Federation dated July 25, 1994.

- No. 13. - Art. 1447.

Arbitration Procedure Code of the Russian Federation dated July 24, 2002 No. 95-FZ // Official Gazette of the Russian Federation. - dated July 29, 2002. - № 30. - Art. 3012 